\title{
STATE MANAGEMENT IN CENTRAL ASIA DURING THE COVID-19 PANDEMIC
}
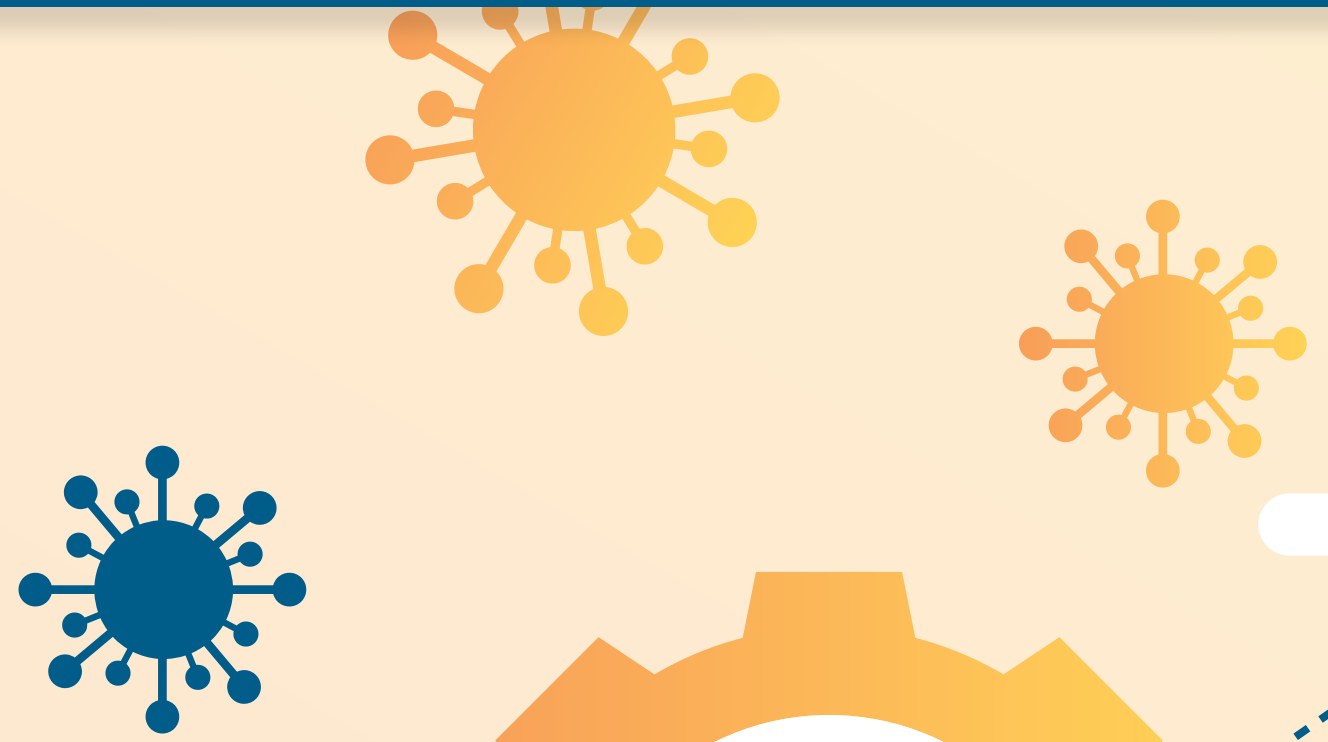
The author of this publication is Aydar Amrebayev, a political analyst from Kazakhstan. The publication analyzes the state management of the Central Asian countries in the fight against the coronavirus crisis, identifies the information background of their support, and provides recommendations for developing regional responses to such crises.

The publication is intended for young experts and consultants, researchers, decision makers, as well as a wide range of readers interested in the politics of the countries of the Central Asian region. The editorial preparation of the publication was carried out by Nargiza Muratalieva, editor of the regional analytical platform CABAR.asia.

The opinions expressed in this document do not reflect the position of the analytical platform CABAR.asia.

IWPR is an international nonprofit organization supporting independent media and civil society in transition countries. It operates in 28 different states and began operations in Central Asia in 1999.

(C) 2020 IWPR, all rights reserved. This material can be copied, downloaded, and printed for personal study, research, as well as for non-commercial training purposes, assuming the obligatory references are made to IWPR, the copyright holder.

This publication was designed in a framework of the project funded by the Government of Norway. The content of the publication should not be considered as an official position of the Norwegian Government. 


\section{CONTENT}

$\begin{array}{ll}\text { ABSTRACT } & 3\end{array}$

$\begin{array}{ll}\text { INTRODUCTION } & 7\end{array}$

KAZAKHSTAN:

COMBINED SUPPORT MEASURES

Public policy during the coronavirus

crisis and new problems

Information policy and digitalization issues

Lessons learned, risks and new opportunities

KYRGYZSTAN: PANDEMIC AS A TRIGGER

FOR A POLITICAL CRISIS

Government response in times of crisis

Information component of the fight

against the corona crisis

The (un) learned lessons

of public management

TAJIKISTAN: OFFICIAL DISCOURSE

OF VICTORY VS REALITY

State support of the national economy

during the lockdown

One-sided information support:

belated and controlled statistics

Recommendations for the modernization

of the public management system

UZBEK WAY TO FIGHT CORONAVIRUS CRISIS

Dilemmas and specifics

of public management

Information support of state policy

Disadvantages and advantages

of the chosen strategy

CONCLUSION

REFERENCE LIST 


\section{ABSTRACT}

This publication is devoted to the study of the features (problems and solutions) of the activities of states in the context of countering the coronavirus pandemic in Central Asia. The article describes the experience of supporting economic activity in the countries of the region under conditions of quarantine, as well as providing the necessary amount of social assistance to vulnerable groups of the population. At the same time, an important component of this experience is the costs of information support during a crisis associated with public self-isolation, the role of the state in informing about the current situation, informing citizens about the methods of personal hygiene, prevention measures and treatment, as well as maintaining social distance. An important area is to contribute to the elimination of the «digital inequality» both in individual countries and in the Central Asian region as a whole.

\section{SPECIFIC FINDINGS BY COUNTRY:}

The experience of Kazakhstan has demonstrated the presence of a high public demand for the modernization of the entire state system, based on modern information technologies of the latest generation. It is necessary to create a particular big data for the entire region in order to develop preventive measures to combat such "challenges", as well as opportunities for adaptation to national systems of high-speed Internet and the principles of digitalization of public services.

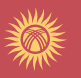

The experience of Kyrgyzstan aims to widely use the potential of civil society in the process of consolidating and mobilizing society to combat such challenges.

The experience of Tajikistan has shown the need for the rational use of international donor assistance in the interests of the population, the creation of favorable complementary relations of interaction between the state and society in the face of a common misfortune.

The experience of Uzbekistan emphasizes the need to combine effective government support for the economically active population who have lost their jobs in the context of a pandemic, and targeted social assistance to vulnerable segments of the population through mechanisms of public mutual assistance in traditional institutions of self-government. 


\section{REGIONAL LEVEL CONCLUSIONS:}

The current coronavirus pandemic has shown that the countries of the region do not have a clear and coordinated system of measures and mechanisms to counter such challenges. The national government agencies responsible for overcoming the pandemic had "isolated themselves" and failed to create precedents for coordinated work to support economic activity, create closed, cluster systems, production chains and online trading platforms for life support in crises similar to the current one. The countries of the region are still critically dependent on the import of medical equipment and anti-epidemiological medicines as a result of the lack of production of their own medical products, equipment, and a significant nomenclature of medicaments. The situation showed weak information infrastructure, technological backwardness of both the region as a whole and individual countries.

All the talk about regional cooperation did not ensure interstate cooperation even at the minimum level. The borders were closed even for the transit of humanitarian aid (medical equipment, medicines, food, etc.) Integration associations in the post-Soviet space (and not only in the post-Soviet space) have shown their inefficiency and inability to respond quickly to such non-traditional challenges.

This challenge once again demonstrated the relevance of institutional interaction between the countries of the region, the creation of effective and responsible platforms for the preparation and adoption of joint decisions to counter such problems in the future.

The coronavirus pandemic has once again revealed and exacerbated the "generic" systemic "weak spots" of the states of the region, which have not completed the formation of stable and modernized sovereign systems, both operational and strategic - political, socio-economic, and cultural-informational moderation of social processes. The unfinished, in most cases, transit of the states of the region to a new quality so far has a serious impact on the stability of the emerging systems and there is no complete confidence in the ability of states to successfully respond to challenges and risks akin to the spread of the coronavirus pandemic. 


\section{REGIONAL LEVEL RECOMMENDATIONS:}

We believe that the coronavirus pandemic can become a particular "case" and trigger for our countries to reach a new qualitative level of institutional cooperation. We consider it expedient to move to the conclusion of a multilateral agreement on the creation of a single humanitarian space, in this case, concerning the preservation of the life and health of citizens with all the necessary regulatory and infrastructural conditions, a common fund for mutual assistance and material reserves, joint channels of information notification, anticipation and consultation, exchange specialists, technical and technological country developments to overcome challenges similar to the coronavirus pandemic, awareness and spread among people of a common ideologeme: "one region - one destiny." This could be the first step towards regional integration in Central Asia in the face of a common danger.

For the Central Asian states, one of the pressing problems of technological development is the elimination of digital inequality, people's access to information and the speed of obtaining it in order to promptly respond to social crises. The expediency of developing region-wide solutions in this matter, creating an open and high-speed information platform space is obvious. For example, in the conditions of quarantine and the transition to distance forms of education, the provision of public services, the current system of information support and existing restrictions have significantly affected the success of the functioning of societies in the context of a crisis of access to information.

The Central Asian region as a whole, as well as individual countries here, found themselves in the conditions of the coronavirus pandemic in the face of inadequacy of their own drug supply resources, the underdevelopment of the pharmaceutical industry and the production of related products. The region found itself in a situation of critical external dependence on the development and promotion of vaccines, with rare exceptions, which is and can continue to be a kind of means of "political blackmail and pressure" from the more developed countries and transnational companies in this respect. In this regard, there is an urgent need for the accelerated development of a regional medical cluster with an advanced pharmaceutical industry and a region-wide culture of prevention of mass diseases, the development of regional healthcare standards, for example, the mutual recognition of "vaccination passports". The culture of social communication of the peoples of Central Asia is characterized by numerous collective events with a large number of people, for example, commemoration,weddings and various family and national holidays, which, 
as shown by the "lessons of the pandemic," often became a source of rapid spread of the disease. In this regard, a conscious public consolidation is also needed to develop and implement new cultural traditions that provide for greater autonomy and an emphasis on safety for the life and health of citizens in conditions such as the coronavirus pandemic.

The challenge of the pandemic is transnational in nature, which requires common approaches to the use of public transport and logistics corridors, the harmonization of border crossing regimes for individuals and cargo in conditions of the risk of transmission of infections. The methods of blocking and closing borders negatively affect the economic aspects of quarantine regimes. As the practice of the first year of the spread of the pandemic in Central Asia has shown, states developed their own formats for the security of national borders in an emergency mode, without considering the interests of each other, which caused significant economic costs to individual countries. In this connection, there is an urgent need for the development and implementation of common regional regulations for the operation of interstate borders in a crisis such as the coronavirus pandemic. This work can be initiated at the Coordination Meetings of the leaders of the Central Asian countries.

A number of problems have arisen associated with the underdeveloped infrastructure of the organization to resist the spread of the pandemic on the part of the state. For example, it was identified the need for timely notification of the population, provision of protective equipment, specialized medical institutions, specialist professionals, the development of up-to-date protocols for the treatment of the disease, the attitude of the population towards vaccination and the choice of effective vaccines by states for use, both in individual countries and in the region as a whole. In this regard, it is necessary for the relevant government agencies of the countries to take targeted steps towards the convergence of health systems and government policies in countering the coronavirus pandemic, adapting WHO recommendations and requirements to national and regional standards in order to achieve the greatest overall, agreed effect.

The countries of the Central Asian region have different capacities and capabilities to counter the pandemic. At the same time, the situation has demonstrated different approaches to the use of these opportunities and means of assistance sent from abroad, varying degrees of development of the volunteer movement within countries. In this regard, it is advisable to disseminate and scale within the region of the experience of public-private partnerships, the participation of the civil sector in minimizing damage from the pandemic, as well as cooperation with international structures to combat coronavirus. 


\section{INTRODUCTION}

Humanity is going through one of the most dramatic periods in its history today, associated with the large-scale, truly global, spread of the COVID-19 pandemic, the consequences of which have yet to be deeply understood, the reasons investigated, and conclusions drawn. One of the problems that the pandemic has revealed to date is the ability / inability of individual states to adequately respond to this "challenge". As it is known, the newly independent countries of Central Asia belong to the group of states that are in transit, and the more interesting is the model of public management in our region during the COVID-19 pandemic. This model or country models make it possible to identify both specific "blunders" and systemic reasons for the lack of a proper response by states to this human misfortune.

We are talking not only about the institutional and functional readiness of government agencies to combat the pandemic, but also a certain type of relationship between states and Central Asian societies, the ability for social mobilization and a certain type of culture of providing public health services. This topic actualizes and exposes many "pain points" of the growth of state institutions in Central Asia and is aimed at describing the features of state "crisis management" in an emergency. In this regard, a comparative research assessment of the features of public administration systems in the countries of Central Asia in the context of the COVID-19 coronavirus pandemic was carried out. This development represents the author's opinion based on the collection of publicly available information and conducted in the countries of the Central Asia region, with the exception of Turkmenistan, round tables and online discussions organized by IWPR in May-April 2020. The study was carried out in a country aspect with general and specific conclusions at both the national and regional levels. 


\section{KAZAKHSTAN: COMBINED SUPPORT MEASURES}

\section{PUBLIC POLICY DURING THE CORONAVIRUS CRISIS AND NEW PROBLEMS}

One of the main preliminary results of the spread of the COVID-19 coronavirus pandemic in Kazakhstan, as in many countries of the world, is the economic costs during the forced lockdown. In comparison with other Central Asian countries, Kazakhstan had possessed sufficient financial resources to combat the spread of the coronavirus pandemic. According to President Tokayev K.K., the fight against the pandemic in the Republic of Kazakhstan cost the budget 13 billion USD, or 8\% of the country's annual GDP.

As part of the quarantine measures, an Interdepartmental Commission on the Non-Proliferation of Coronavirus was created: a state of emergency was declared, recommendations were developed for transferring the activities of state, public and private institutions to a remote work format, borders were closed for foreign citizens and food price control was introduced. Moreover, monitoring of the dynamics of the spread of the pandemic in the context of regions and notification of the population regarding this matter was introduced in the media, as well as work was carried out on thematic advertising and information materials on the prevention of coronavirus.

Regarding health support, the following activities were carried out: disinfection of large cities; free medical care (for all citizens until July 1); construction of specialized medical institutions of a narrow profile (a special hospital for patients with coronavirus was built in Nur-Sultan); control of prices and nomenclature of medicines through the pharmacy and hospital networks; mobilization of medical workers to work in special departments for coronavirus and material incentives for their activities.

In order to support the level of income of the population, social protection measures were expanded: subsidizing wages and unemployment benefits ("package of anti-crisis measures"). An additional 1 trillion tenge was directed to support employment within the framework of the Employment Roadmap program.

\footnotetext{
1 "Tokayev: The Fight Against Coronavirus Cost Kazakhstan Almost 6 Trillion Tenge," Informburo, May 5, 2020, https://informburo.kz/novosti/tokaev-borba-s-koronavirusomoboshlas-kazahstanu-pochti-v-6-trln-tenge--106068.html [in Russian]

2 "On the Approval of the Employment Roadmap for 2020 - 2021: Order of the Prime Minister of the Republic of Kazakhstan dated March 27, 2020, No. 55-r" https://adilet.zan.kz/rus/docs/R2000000055 [In Russian]
} 
Lump-sum social payments were provided to the population in the amount of the minimum wage (42,500 tenge per month) at the time of the introduction of the state of emergency. The quarantine was lifted in three stages, with a gradual resumption of economic activity from the end of April and the lifting of the state of emergency on May 11, 2020.

\section{Fiscal actions for legal entities included:}

- Allocation of 600 billion tenge to SMEs for financing working capital, supporting enterprises with liquid funds ("package of anti-crisis measures"). ${ }^{3}$

- Temporary tax breaks as part of the government's anti-crisis package.

- State "package of anti-crisis measures" totaling 10 billion USD. Expansion of subsidized lending from 600 billion tenge (1.5 billion USD) to 1 trillion tenge and reducing interest rates from $13-15 \%$ to $6 \%{ }^{4}$ Announcement of the government's Comprehensive Growth Recovery Plan to stimulate business activity, support employment and increase income.

\section{Expansion of subsidized lending}

Was

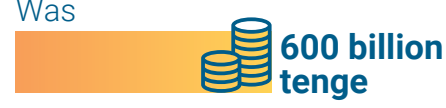

Became

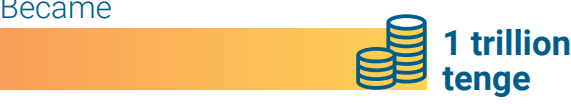

\section{Reducing interest rates}

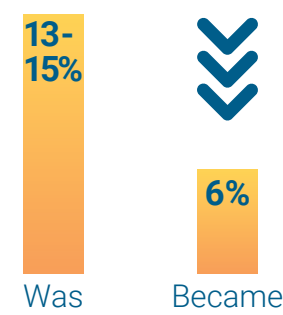

- The refinancing process for commercial banks was simplified, and prudential regulation was relaxed.

On the initiative of the first president of the Republic of Kazakhstan, the Birgemiz fund was created, which attracted funds from philanthropists, businessmen, and statesmen.

As one can see, in Kazakhstan, at the initial stage, all necessary institutional and functional measures of social support of the population were implemented, a package was proposed to preserve jobs, retention of business processes, measures were taken to mitigate or postpone the credit burden for the economically active population, despite a tough lockdown. However, in the process of unprecedented social policy of the state, negative characteristics of state management and its "old sores", such as systemic corruption, were revealed.

\footnotetext{
3 "600 Billion Tenges Will be Allocated to Banks for Lending to SMEs in a Crisis," Zakon.kz, March 20, 2020,

https://www.zakon.kz/5012701-600-mlrd-tenge-vydelyat-bankam-dlya.html [In Russian]

4 "Anti-crisis Measures of the Government: Resumption of Economic Growth and Support for SMEs," Official information source of the Prime-Minister of Republic of Kazakhstan, https://primeminister.kz/ru/news/reviews/antikrizisnye-mery-pravitelstva-vozobnovlenie-rosta-ekonomiki-i-podderzhka-msb-862620 [In Russian]
} 
Many positive social initiatives of the country's leadership could not reach the addressee in full. At different levels of the bureaucratic hierarchy in the center and in the localities, there were facts of misappropriation of allocated funds, incompetent management, and mismanagement. Former Minister of Health Yelzhan Birtanov is suspected of embezzling budget funds on an especially large scale and is under house arrest, ${ }^{5}$ and the ex-head of SK-Pharmacy, which is a distributor for the purchase of medicines and medical products to ensure the volume of free medical care, is also under investigation. ${ }^{6}$

As one can see, even the most impressive sums with ineffective institutions and systemic problems, when money does not reach the addressees, will not rectify the situation, which was the case in Kazakhstan as well. The distribution of public funds for the fight against the pandemic was sporadic and "campaigning" in nature. Along with substantial social assistance to the affected population and, especially to doctors who were on the front lines of the disaster response, support for the economically active population was clearly insufficient, which led to the forced stop of the strict quarantine in May.

Despite the understanding of the need for substantial support for business, assistance from the state was focused mainly on large enterprises with a large number of workers and a significant share of participation in the national economy, as well as businesses close to the government, while broad sections of small and medium-sized businesses, self-employed, in fact, were left without support from the state and were even subjected to "verification repressions" by state agencies.

In this regard, the socially "sensitive" sectors of the economy related to public catering, the service sector, trade in consumer goods, the leisure industry, tourism, etc., had "dropped". The damage is not only in the overall decline in the gross indicators of the economy, but in drawbacks, associated with a decrease in the quality of economic assets of the state, paralysis of the economic activity of the population, hopelessness, and the closure of many businesses. The stratum of the large quasi-business sector, which was affiliated with the bureaucracy, designed for "business at the expense of the state," was unable to assume responsibility and the main burden amid the economic crisis associated with the spread of the pandemic. Thus, a fairly thin layer of SMEs in Kazakhstan today is experiencing significant problems associated with simple survival.

\footnotetext{
5 "Birtanov's Arrest was Extended Until the End of February," Kursiv.kz, January 20, 2021, https://kursiv.kz/news/obschestvo/2021-01/birtanovu-prodlili-arest-do-konca-fevralya [In Russian]

${ }^{6}$ Rabiga Dysengulova, "There is One Suspect in the SK-Pharmacia Case," Tengri News, January 29, 2021,

https://tengrinews.kz/crime/v-dele-sk-farmatsii-odin-podozrevaemyiy-427405/ [In Russian]
} 
According to Halyk Research, in the first half of 2020, the profit of small businesses fell by almost a third on an annualized basis: trade (-33\% y / y), the financial sector $(-45 \%$ y / y), mining $(-84 \%$ y / y) d).

Profit of small businesses in the first half of 2020

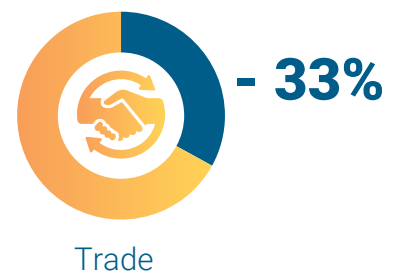

Trade

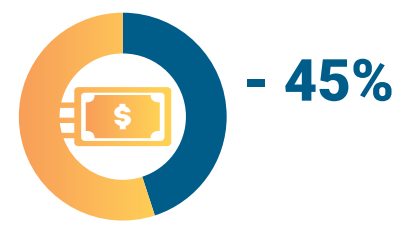

Financial sector

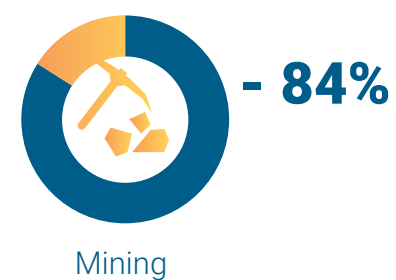

In the context of a pandemic, the state has demonstrated effectiveness in establishing control systems over economic entities, replenishing the budget at any cost, while measures to stimulate and support business have turned out to be in the background. This condition exacerbated the situation of alienation of the economically active population from state development programs and increased the index of distrust in government agencies, which were perceived as "punitive structures" in the public perception, which increases the degree of social tension, discontent not only from socially vulnerable segments of the population, but also from the economically active middle class, encourages "leave the country" sentiment. Kazakhstan is a leader among the EAEU countries in terms of the outflow of human capital, experts note that this trend is largely associated with widespread corruption, lack of career opportunities, nepotism, problems in the education and health care systems, along with other reasons. ${ }^{8}$

In the scenario of a worsening situation in the second phase of the pandemic, many of the government's macroeconomic plans will not be implemented or reduced, issues of economic diversification, a "business roadmap", programs for accelerated industrial and innovative development and, in general, the business climate in the country will significantly worsen, which can lead not only to a decrease in the rate of economic development, but also to a deterioration in the quality of the economy, imbalances in development and social shocks.

Despite the fact that the state continues to take unprecedented measures to support vulnerable segments of the population, this does not stimulate the improvement of the situation in all other senses, as stimulating socially active and capable segments of the population. This can lead to a decrease in human resources and the washing out of social capital, an increase in migration sentiments among people, distrust to the authorities, even leading to actions of civil resistance.

\footnotetext{
7 "Small and Medium Enterprise (SME) Sector Survey," Halyk Finance, October 23, 2020, https://halykfinance.kz/download/files/analytics/sme2020.pdf [In Russian]

${ }^{8}$ Sergey Smirnov, "The Retreat from Kazakhstan Continues," Rhythm of Eurasia, December 17, 2020, http://www.ritmeurasia.org/news-2020-12-17-ishod-iz-kazahstanaprodolzhaetsja-52415?fbclid=IwAR1S-Du_UYIFX-d076cNhkHtoPGapKy1h_nga7wEFcutbBBM0ZKBbxyxS30 [In Russian]
} 
Unfortunately, government support measures are aimed at solving tactical problems when strategic goals remain out of sight and may negatively affect in the near future. The emergency situation associated with the coronavirus crisis significantly influenced the active participation of civil society in solving important problems of state development, lowered the "threshold of sensitivity" of society to violations of human rights and the strengthening of authoritarian tendencies in public administration.

In a situation of passivity and apathy on the part of the socially active stratum of the population, thus disadvantaged, it can lead to the inhibition of the mechanisms of support and participation of citizens in governing the state and, in general, to social activity. The alienation of citizens from their state can stimulate stagnant social processes and increase the state's vulnerability to internal and external challenges.

\section{INFORMATION POLICY AND DIGITALIZATION ISSUES}

The conditions of social crises, such as the spread of the coronavirus pandemic, are a certain test for the information openness of the state, its ability to adequately interpret the difficulties arising in society and to respond pointwise by developing effective programs to counter the crisis. In Kazakhstan, in general, during the period of the spread of the pandemic, sufficiently effective methods of state information policy to counter the pandemic were observed, in particular, information on the spread of the pandemic in the country, in the context of regions, statistics on the number of victims, sick and recovered were promptly covered. State measures to prevent proliferation, campaign materials to improve the sanitary and hygienic condition in the country were covered. At the same time, especially at first, there were ambiguities with the classification of diagnostics of patients according to the signs of coronavirus, on the one hand, and pneumonia, on the other. This problem was important for understanding the true scale of the pandemic and developing effective policies to counter it.

\section{HOWEVER, THE DIGITALIZATION SYSTEM} HAS SHOWN ITSELF TO BE INSUFFICIENTLY EFFECTIVE IN THE CONTEXT OF THE CORONAVIRUS CRISIS, TO WHICH THE STATE HAS GIVEN ONE OF THE PRIORITY ATTENTIONS THROUGHOUT THE ENTIRE NEAR FUTURE.

In a number of cases, the system of information support of public services failed due to technical imperfections. This had the most negative impact on the provision of services to the population, in the education system, social security, and health care. At first, the state was not ready 
to switch to a remote form of activity, which often "froze" the activities of various state and non-state institutions. The information and technical infrastructure did not adequately respond to the emerging crisis situation, which demonstrated the costs of the state's technological development. It is critically important to provide certain segments of the population with computers and ubiquitous connection to the global network. The lack of a legislative framework in this area also served as an obstacle to a qualitative transition to the remote formatб where the government had to hastily develop appropriate methodological recommendations, instructions, and regulations. ${ }^{9}$

In terms of forecasts for the near future, it should be noted that both in the state and non-state sectors, there is a noticeable revival in the use of information technologies in establishing public communication, the widespread transition to its remote formats. However, in this regard, there is a certain "fatigue" in society from the excessive use of "remote communication". This can change, and not always in a positive way, the traditions of social communication adopted in Kazakhstan, change the quality and principles of organizing social capital in the country.

\section{LESSONS LEARNED, RISKS AND NEW OPPORTUNITIES}

Speaking about the "lessons" of the first stage of the coronavirus crisis for the public administration system in Kazakhstan, it should be noted that the rather cumbersome public management system was more adapted to decision-making processes in the normal mode, while it was not ready for a crisis situation and required serious modernization.

\section{WE BELIEVE THAT IT IS NECESSARY TO IMPROVE THE SYSTEM OF VERTICAL AND HORIZONTAL SOCIAL COMMUNICATIONS, ESPECIALLY IN TERMS OF IMPLEMENTING GOVERNMENT INNOVATION TO FORM A “HEARING STATE” IN KAZAKHSTAN.}

There is a need for more mobile and adaptive to crisis situations warning and decision-making systems at the local level, the issue of the development and expansion of public self-government is especially urgent. The information and technological infrastructure of the state requires significant changes, digitalization, overcoming the "digital inequality".

\footnotetext{
${ }^{9}$ Ayim Saurambayeva, "Difficulties of Transition to Distance Education: the Case of Kazakhstan," CABAR.asia, August 24, 2020, https://cabar.asia/ru/trudnosti-perehoda-nadistantsionnoe-obrazovanie-kejs-kazahstana [In Russian]
} 
The actions of the state during the first phase of the coronavirus epidemic demonstrated a number of "systemic sores" in public administration, one of the manifestations of which was the monopolization of the distribution system, in this case, medicines in the hands of quasi-market national companies, as a result of which there was a shortage of medicines and necessary medical equipment in the summer, which entailed drastic consequences - an increase in the death toll from COVID-19. The country's leadership had to accept cardinal organizational conclusions, change the heads of the Ministry of Health, a number of national companies, in respect of which a criminal investigation is underway on the fact of misappropriation of funds, excess and improper performance of official duties. There was also an irrational spending of funds on the construction of low-capacity inpatient medical institutions, the provision of contracts to affiliated companies, which, in the face of an increase in the number of people in need of inpatient treatment, failed to meet the necessary needs. The incompetence of the health authorities also manifested itself in the unpreparedness of local medical personnel to work with special equipment, the lack of transparency in the provision of material incentives and compensation to health workers in the event of illness and death. And this despite the fact that the government has approved the required amount of material compensation. There is an obvious incompetence, lack of transparency in the activities of state bodies, the affiliation of officials with large commercial structures and a high level of corruption associated with irresponsibility, both in central and local bodies.

Experts identified a number of risks for the development of the situation in connection with the spread of the pandemic: The first risk is associated with insufficient support and incentives for small and medium-sized businesses, adaptation of the self-employed in crisis conditions, transfer of responsibility and social burden to large business and the quasi-public sector. The second risk, also noted by international experts, is the loss of jobs, a reduction in wages, and a significant decline in the standard of living of the population. The third risk is a decrease in consumer activity of the population, which will reduce the capacity of the national market and, as a result, reduce the potential for market regulation of the economy. Significant changes in the quality of consumption and the format of service provision are expected, as well as the transition to the online format. The fourth risk is a decrease in the investment attractiveness of Kazakhstan. The fifth risk is an increase in the degree of social tension and the presence of serious political risks in this regard.

However, there are also certain opportunities, new directions that can be used. The first is the motivation for the development of the digital sphere, which will affect science, education, medicine, the provision of services, etc., which will allow reaching the next level of technological development. The second is telecommuting (distance working), which changes the approach to organizing work (even in the public sphere) in terms of optimizing business processes and saving "inactivated infrastructure". 
The third is a chance for self-sufficiency, real economic diversification and import substitution. The isolation trend in modern conditions is dominant and this is an opportunity to conduct a kind of audit of the real capabilities of the state, the stability and strength of national capital and the possibilities of its mobilization to solve super-tasks. Fourth, the main acknowledged priority of state policy is the protection of public health, opportunities for the development of human resources through education. Fifth, a high public demand for high-quality state management and modernization of the entire state system, which is responsible for the life support of society. 


\section{KYRGYZSTAN: PANDEMIC AS A TRIGGER FOR A POLITICAL CRISIS}

\section{GOVERNMENT RESPONSE IN TIMES OF CRISIS}

The financial capabilities of the Republic of Kyrgyzstan in terms of mobilizing resources to fight the coronavirus were very limited. However, even in these conditions, the government took a number of economic and fiscal indulgences for business and the population. Thus, measures were taken to postpone tax deductions, tax sanctions and penalties for late payment of taxes were temporarily canceled, and a moratorium on checking business entities was introduced. The government recommended that private enterprises, whenever possible, provide their workers with a minimum income during the period of forced unemployment.

Quarantine measures included the creation of an operational headquarters to monitor the situation on the coronavirus, the introduction of a state of emergency, temporary ban on the entry of foreign citizens, restriction of movement within the country, as well as the closure of schools and public places. The cancellation of quarantine measures was carried out in three stages of the resumption of economic activity by the beginning of May and was completed by the third week of May 2020.

As part of health support, a contingency plan was adopted, the expansion of testing and the introduction of a single reference number, as well as training of medical staff, and so on.

\section{Fiscal measures for legal entities included the following measures:}

- Financing: suspension of loan payments, support of enterprises with liquid funds.

- Taxation: extension of deadlines for filing tax returns, cancellation of fines, electronic system of fiscalization of tax procedures.

- Extension of the moratorium on inspection of SMEs (small, medium-sized enterprises), improvement of the business climate for SMEs, information campaigns directed at SMEs. Revision of public procurement policy. Recommendations for deferring rent and utility payments.

Macroeconomic and prudential regulation consisted in maintaining the key rate at $5 \%$, reducing the requirement for the minimum required bank reserves, and reducing the liquidity ratio. 
In the field of social support, the government canceled the appointment of fines and penalties for utilities, Internet providers were advised not to turn off Internet services for having arrears. Moreover, the government has pledged to pay an additional 46 thousand KGS (540 USD) on top of their basic salary for medical workers involved in identifying and treating patients with coronavirus. ${ }^{10}$ In addition, the government decided to provide compensation to doctors in case of infection with coronavirus or death from the effects of the virus.

In the field of finance, the government has taken measures to amnesty credit obligations, primarily taken in US dollars. Commercial banks have postponed the payment of loans to all individuals and legal entities temporarily without income for three months.

In order to regulate prices for food and medicine, fines for unjustified increases in prices for food and medicine have been increased. Furthermore, in order to increase the responsibility of citizens during an emergency and a state of emergency, the government has made changes that toughen the responsibility for a number of rules in force during the coronavirus period. Violators of the order will face liability from a fine to a real criminal term of 2.5 to 5 years.

Thus, state support measures are more effective in the field of medical and sanitary control as well as law and order, that is, where employees of budgetary organizations are involved.

\section{THE GOVERNMENT'S ANTI-CRISIS PLAN} IS FOCUSED MAINLY ON THE SPHERE OF BUDGETARY ORGANIZATIONS AND, TO A LESSER EXTENT, ON SUPPORTING BUSINESS ENTITIES.

Unlike other Central Asian countries, Kyrgyzstan has experienced an unprecedented activity of civil society and volunteers in terms of social support of the population, at the initial stage, by supporting the poor with food products, and then by supporting medical workers and specialized institutions. However, social assistance to the needy population was not coordinated, the government and civil society acted separately in the context of the pandemic at their discretion.

Over one and a half million US dollars ${ }^{11}$, have been accumulated in the special volunteer fund, for comparison, the budgetary revenues of the whole country amount to about 2 billion US dollars. Civil activity

\footnotetext{
${ }^{10}$ Arsen Usenov, "Problems of Ensuring the National Security of Kyrgyzstan amidst the Current Crisis," CABAR.asia, April 20, 2020, https://cabar.asia/ru/problemy-obespecheniyanatsionalnoj-bezopasnosti-kyrgyzstana-v-usloviyah-nastupivshego-krizisa [In Russian] ${ }^{11}$ Arsen Usenov, "Problems of Ensuring the National Security of Kyrgyzstan amidst the Current Crisis," CABAR.asia, April 20, 2020, https://cabar.asia/ru/problemy-obespecheniyanatsionalnoj-bezopasnosti-kyrgyzstana-v-usloviyah-nastupivshego-krizisa [In Russian]
} 
at the initial stage of the coronavirus pandemic significantly "raised the spirit of the population and the desire for solidarity, especially among urban youth, ${ }^{12}$ which later became one of the "catalysts" for the "revolutionary changes" that took place in the ruling Olympus.

On the threshold of the second phase of the coronavirus, there was a mood of disappointment and lack of trust between society and the state, which could have the most negative impact on the effectiveness of the fight against the pandemic, the growth of cases and deaths as a result of the lack of an effective decision-making center. The state system of Kyrgyzstan itself is experiencing an acute crisis of both institutional and functional nature, and most importantly, a crisis of public trust and dialogue with the general population.

Nevertheless, Kyrgyzstan today is in a situation of the most severe socio-economic and political crisis, which significantly limits the possibilities of combating the coronavirus, both on the part of the state and on the part of civil society. There are purely economic parameters for the onset of the crisis. According to the Ministry of Finance, the state budget deficit at the beginning of 2020 was 27.7 billion KGS, and as of November 2020 - 35 billion KGS. ${ }^{13}$ The national debt rose to 4.6 billion USD, or $60.2 \%$ of the GDP. ${ }^{14}$ More than 1 million people are outside the country and carry out labor activities, more than 700 thousand citizens of Kyrgyzstan are working in Russia (about $24 \%$ of the working population. ${ }^{15}$ Labor migrants are the main source of stabilization of the internal economic and social situation in the country, since they serve as a source of income for many Kyrgyzstanis. The role of remittances from neighboring countries in the country's economy is colossal. So, from January to October 2020, migrants transferred to Kyrgyzstan over 2 billion USD, which is about a third of the GDP of the Kyrgyz Republic. ${ }^{16}$

One of the social foundations of the outbreak of social tension and political crisis that took place in Bishkek was a decrease in the volume of cash receipts from labor migrants and the return of many of them from abroad, in connection with outbreaks of coronavirus in countries of labor migration donors and restrictions introduced there, as was the case in Russia. According to the Central Bank of the Russian Federation, in percentage terms, remittances in the second and third quarters of 2020 to Kyrgyzstan decreased by $26 \%$. $^{17}$

\footnotetext{
12 ibid.

13 Ilham Saypidinov, "The Growth of Gold and Foreign Exchange Reserves of the National Bank of the Kyrgyz Republic against the Background of a Decline in GDP is One of the Reasons for the Devaluation of the Som," Akchabar, https://www.akchabar.kg/ru/article/opinion/rostzolotovalyutnyh-rezervov-nacionalnogo-banka-na-fone-spa/ [In Russian]

14 ibid.

15 Zhamilya Zhakypbekova, "Public debt, Poverty and Migration. Will the new

Constitution Help Solve these Problems?" Economist, https://economist.kg/2020/11/24/

gosdolg-bednost-i-migraciya-pomozhet-li-novaya-konstituciya-reshit-eti-problemy/

16 "In Recent Months, Migrants' Remittances have Increased - Data from the NBKR," December 19, 2020, https://ru.sputnik.kg/migration/20201219/1050823724/kyrgyzstan-perevody-migranty.html [In Russian]

${ }^{16}$ Yrysbek Ulukbek ulu, "Remittances from Russia have Plummeted: Kyrgyzstan will Suffer More than it Seemed," Radio Azattyk, https://rus.azattyk.org/a/30611906.html [In Russian]
} 
People of active working age found themselves "out of work" and without proper socialization at home, and their families without means of subsistence. Such a mass of people marginalized in this way is a source of revolutionary collisions, which happened in October 2020.

\section{Decrease of remittances from Russian Federation}

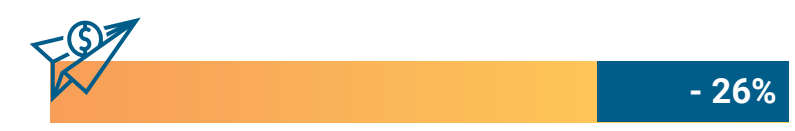

The general decline in the country's macroeconomic indicators, corruption, extreme dependence on imports, especially in the field of food supply, the fuel and energy sector, etc., dependence on external donors and loans from foreign countries created a situation of acute budget deficit comparable to 1995. The tourist season of 2020 turned out to be a "failure" due to an $80 \%$ decrease in the tourist flow. ${ }^{18}$ According to World Bank forecasts, the largest drop in GDP in 2020 was expected in Kyrgyzstan, minus $12 \%$. However, according to the latest WB estimates, the fall in GDP in 2020 in this country is estimated at minus 8 percent. ${ }^{19}$

\section{INFORMATION COMPONENT OF THE FIGHT AGAINST THE CORONA CRISIS}

Kyrgyzstan, in comparison to the rest of the Central Asian republics, has significant advantages in terms of freedom of speech and the activities of civil society. In general, the topic of the coronavirus pandemic was open, and the awareness of the population was sufficient to take the necessary measures. On the one hand, in Kyrgyzstan, data on the first cases of infected people were timely made public, government agencies sought to transparently keep statistics on cases of coronavirus, also combining data on cases with pneumonia. However, according to the latest data, there are officially voiced assumptions that the real mortality rate from coronavirus may be three times higher than the official data. ${ }^{20}$

Information channels and the situation around the coronavirus were often used in the internal political struggle, which led to a rather destructive information background around this acute problem. Civil activists, as it turned out, rightly accused some state bodies of the lack of transparency in the distribution of humanitarian aid and the absence of an information policy in this direction. As a result, to date, several criminal cases have been opened regarding the corruption component during the receipt and distribution of humanitarian aid. ${ }^{21}$

\footnotetext{
18 "Minister of Culture and Tourism of Kyrgyzstan: It Will Take Several Years to Restore Tourism in the Country After the Pandemic", Interfax, https://www.interfax.ru/interview/722563 [In Russian] 19 "Global Economic Prospects Europe and Central Asia Regional Overview," World Bank, January 2021, http://pubdocs.worldbank.org/en/996111599838731966/Global-EconomicProspects-January-2021-Regional-Overview-ECA-RU.pdf

20 Zamira Kozhobaeva. "COVID-19 in the Kyrgyz Republic: Real mortality may be three times higher than official data," Radio Azattyk, January 20, 2021, https://rus.azattyk.org/a/covid-19v-kr-realnaya-smertnost-vyshe-ofitsialnyh-dannyh-v-tri-raza/31053269.html [In Russian] ${ }^{21}$ Bakyt Asanov, "The former-head of the Ministry of Health of the Kyrgyz Republic, Suspected of Corruption, Was Hospitalized After Interrogation," Radio Azattyk, July 11, 2020, https://rus. azattyk.org/a/30720815.html [In Russian]
} 
From the point of view of focusing public attention on the fight against coronavirus, educating the population on public hygiene measures, prevention and treatment, the role of the state's information policy turned out to beinsignificant. Information was mainly transmitted via social networks and various telegram channels, etc. Despite the fact that the Republican headquarters for the fight against coronavirus made many decisions and issued protocols, most of them were not enforced on the ground. ${ }^{22}$

In addition, the state deliberately did not deal with the issues of largescale social digitalization of its activities and faced rather severe consequences of "information inequality", especially between residents of cities and villages. At the same time, an average of two out of three families (70\% ${ }^{23}$ have Internet access. The World Bank estimates that the most vulnerable are students from low-income families, remote areas, minorities, and people with special needs.

\section{An average of two out of three families have Internet access}
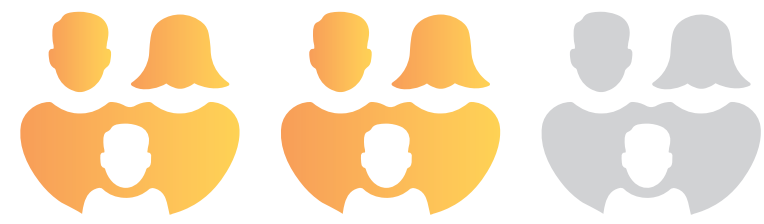

The absence of a single coordinating information center for monitoring the situation, timely notification and informing people about the measures taken by the government, vertical and horizontal social communication, in fact, has provided at the mercy of not always "conscientious people" an up-to-date information agenda. As a result, there was a "gap" in the population's awareness of current events, perception priorities and the need for social mobilization on certain issues.

In general, we can say that the information environment around the problem of the effectiveness of public management in the fight against the COVID-19 coronavirus pandemic played a negative role in discrediting government institutions in the eyes of society and the emergence of ochlocratic tendencies in public consciousness and behavior. Ultimately, this situation became the driver of the socio-political crisis that gripped the country.

\section{THE (UN) LEARNED LESSONS OF PUBLIC MANAGEMENT}

The situation in the Kyrgyz Republic is characterized by a serious dysfunction of the public administration system. By the standards of WGI (Worldwide Governance Indicators), the assessments of the public administration system are very low. The state turned out to be weak in terms of efficiency criteria, such as 1) satisfaction of social needs; 2) optimal use of development resources.

\footnotetext{
22 Zamira Kozhobaeva, "COVID-19 in the Kyrgyz Republic: Real mortality may be three times higher than official data," Radio Azattyk, January 20, 2021, https://rus.azattyk.org/a/covid-19-vkr-realnaya-smertnost-vyshe-ofitsialnyh-dannyh-v-tri-raza/31053269.html [In Russian]

23 "Educational Inequality: In Kyryzstan, Only One Third of Families have a Computer or Tablet," Media Sabak, https://mediasabak.org/ru/news/209/ [In Russian]
} 
At the initial stage of the spread of the pandemic, the most important expectation from the government was to stop the transmission of infection and save lives. For this, quarantine was introduced at the end of March, but containing the spread of the infection turned out to be the only goal set by the state. The required socio-economic basis, political-administrative and informational resource for overcoming the virus was not created. The overwhelming majority of decisions were in the form of a "bureaucratic alibi" that speaks about the problem but does not solve it. Ex-post decisions were made (a reaction to an already existing situation), reliance was made on rigid administrative and administrative methods "prohibit", "restrict", there were abstract formulations of decisions, international experience was not taken into account and there were no mechanisms for implementation, practical execution and control. ${ }^{24}$ The public management system faced an absolute unpreparedness for a crisis situation, while the desire of civil activists and volunteers to "help the state" to cope with the coronavirus crisis was perceived as quite hostile. The population was practically face to face with the disease.

As a result, "bureaucratic alibis", psychological traps on the side of the authorities (underestimation of danger, overestimation of possible success, etc.), a low level of public confidence in the state and a corruption component led to decisions with low efficiency and increased risk of the spread of the virus.

At the same time, the "Kyrgyz case" demonstrated a significant potential for mobilizing civil society in terms of consolidating and mobilizing the population to fight the pandemic. Unfortunately, the government failed to act as a unified center for coordinating society in the fight against the coronavirus crisis. The power "locked in" on its own problems of intra-elite rumbles, which led to alienation and rejection of managerial decisions, devaluation of power in general and, ultimately, to its downfall.

The lesson of this situation indicates that the isolation of the authorities from pressing social problems, the lack of transparency, the backstage and corruption of the authorities' actions can lead to a coup d'etat. The government agencies failed to objectively assess the scale of "threats and risks", to take the necessary management decisions in a preventive manner, to carry out a direct open dialogue with society, and to consolidate the population to counter the pandemic. The state must become transparent and accountable, where civil society must be seen as a partner, and not as an opponent of the state.

\footnotetext{
${ }^{24}$ Lyudmila Khasanova, "Bureaucratic Alibi and Psychological Traps: How Kyrgyzstan Allowed the Outbreak of Coronavirus," Central Asian Analytical Network, https://caa-network.org/archives/20124 [In Russian]
} 
TAJIKISTAN:

OFFICIAL DISCOURSE

OF VICTORY VS REALITY

\section{STATE SUPPORT OF THE NATIONAL ECONOMY DURING THE LOCKDOWN}

In the context of the economic recession associated with the coronavirus pandemic, although Tajikistan comes out with fewer human losses, nevertheless, the economic and political risks are very high. The government's activities were aimed at maintaining the standard of living of the population: as in other countries, an operational headquarters to counter coronavirus was created, borders and international airspace were closed. Regulation of food markets was introduced (price controls, a ban on the export of basic food products), educational institutions were closed, and restrictions were placed on holding mass events

Stimulation of business activity was carried out through easing fiscal policy, preferential lending, and deferred tax payments, subsidizing the most affected industries, developing incentives to support small businesses, the private sector, and the service sector, which include tourism, hotels, handicrafts, dekhkan (peasant) farms. Of particular note is the allocation of additional funds for the social sector, an increase in the amount of benefits to support families with children, as well as financial assistance to labor migrants who have stayed at home.

The main actions of the government, in addition to directly combating the spread of the coronavirus pandemic, were aimed at minimizing the consequences of the general macroeconomic crisis in the country, supporting the social sphere, transparency of monetary and financial regulation, curbing the weakening of the national currency, reducing rates on additional costs, and suspending financing of high-cost projects.

\section{THAT IS, IN PUBLIC MANAGEMENT, THE EMPHASIS WAS ON MAINTAINING SOCIO-ECONOMIC RESILIENCE, AND NOT A DIRECT RESPONSE TO THE SPREAD OF THE COVID-19 CORONAVIRUS PANDEMIC.}

In Tajikistan, enterprises that provide services to the population resumed their work relatively quickly, but with the observance of preventive measures, while in neighboring countries they came out of the lockdown very slowly and progressively. Accordingly, the business losses, which are and will be, turned out to be not as high as, for example, those of the neighbors. 
A role here was played by the fact that quarantine measures in the republic were not as long as, for example, in Kazakhstan or Uzbekistan. In 2021, according to the World Bank, Tajikistan's GDP growth is projected at 3.5 percent (forecast in October 2020 - 6 percent). ${ }^{25}$

Speaking about support from the state for economic activity, it must be said about several areas of support for replenishing the country's budget:

1. this is the tourism industry, which, in the context of the global pandemic, is the most affected industry due to quarantine measures in potential visiting countries.

2. this is a decrease in remittances from labor migrants from Russia in the context of a complication of the situation with a pandemic in this country.

A significant source of the country's income comes from remittances: in 2019, labor migrants transferred over 2.7 billion USD to the republic, which amounted to about $30 \%$ of the country's GDP. ${ }^{26}$ In 2020, according to Bloomberg, remittances from Russia to Tajikistan decreased by $50 \%$. Depending on the duration of the self-isolation regime, the migrants themselves suffered, due to the fact of paying for work permit, registration and banal survival in a pandemic. This situation is a dead end, on the one hand, due to the fact that migrants cannot earn and pay for their patents, registration and, on the other hand, they cannot return to their homeland due to the closure of the borders of the Russian Federation.

\section{Decrease of remittances from Russia to Tajikistan}

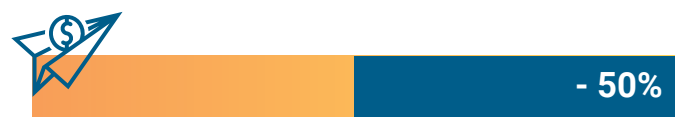

3. an important factor is the improvement of budget regulation, transparency of tax revenues and targeted budget expenditures for supporting programs. We can say that the pandemic has complicated the already difficult situation with the budgetary provision of progressive economic development. The available reserves of the National Bank, according to experts, may turn out to be insufficient to support the country's economy during the crisis. According to the IMF, in terms of GDP, the worst situation will occur in Tajikistan, where the deficit will widen to almost $6 \%$ of GDP. ${ }^{27}$

\footnotetext{
25 "Global-Economic-Prospects, Europe end Central Asia Regional Overview," World Bank, January, 2021, http://pubdocs.worldbank.org/en/996111599838731966/Global-EconomicProspects-January-2021-Regional-Overview-ECA-RU.pdf

26 "The Amount of Remittances in Tajikistan are Decreasing, Income of Citizens is Falling, and Prices are Rising," CABAR.asia, December, 1 2020, https://cabar.asia/ru/v-tadzhikistaneobemy-denezhnyh-perevodov-sokrashhayutsya-dohody-grazhdan-padayut-tseny-rastut [In Russian]

27 Imanbekova Nazik and Khasanova Savia, "Economy and COVID-19 in Central Asia," Central Asian Analytical Network, August, 12, 2020, https://caa-network.org/archives/19734 [In Russian]
} 
4. this is external assistance in the face of the danger of the spread of the coronavirus pandemic in Tajikistan. Tajikistan is asking creditors to defer debt payments and is going to take new loans at the same time. ${ }^{28}$ It is also noteworthy that according to the assurances of the authorities, Tajik state employees voluntarily transferred part of their salaries to the fund to fight COVID-19. Although, on anonymous terms, some civil servants asserted that no one asked their permission for such "voluntary-compulsory actions". ${ }^{29}$

For Tajikistan, social programs and the maintenance of their financing are critically important, in particular, in the absence of large industrial facilities and a capacious consumer market, as well as in the absence of migration support for the economic well-being of the majority of the country's population from outside. The spread of the coronavirus pandemic disrupts the current state of affairs in the country, a certain socio-economic structure. In this regard, this is a direct threat to public safety, but not in the sense of infringement of human rights in the traditional logic, but rather in terms of the destruction of the social stability of the state, the traditional social structure, the experience that the country practiced during the civil war in Tajikistan, therefore an essentially paternalistic state seeks to guarantee security and stability to people in exchange for their freedom and rights.

An important aspect of Tajikistan's state policy in the "era of a pandemic" is the fair and "transparent" distribution of foreign aid from donor organizations and individual countries. This situation is very "sensitive" from the point of view of a kind of "honesty test" of the state management system, the fight against shadow capital and corruption. The absolute support of the population for the current policy in the country indicates that at the moment there is a certain social compromise in the country that allows "to keep the situation under control." However, the challenge of the coronavirus pandemic makes its demands on improving the social infrastructure of the state, in particular, improving the health care system and education, as well as equitable social security.

\section{ONE-SIDED INFORMATION SUPPORT: BELATED AND CONTROLLED STATISTICS}

In the context of the spread of the coronavirus pandemic, timely and objective information to the population, monitoring the situation and a broad dialogue between the state and society on topical development issues are of great importance. An urgent problem remains the issue of medical education in the context of the spread of a pandemic, methods of personal hygiene, prevention of diseases and methods of treatment.

\footnotetext{
28 'Tajikistan Requests the Previous Loans' Deferral and Simultaneously Applies for the New Ones," CABAR.asia, January 26, 2021, https://cabar.asia/ru/ tadzhikistan-prosit-otsrochki-po-starym-kreditam-i-odnovremenno-prosit-novye 29 "We Have no Other Choice." Salary is Partially Taken Away from Civil Servants in Tajikistan," CABAR.asia, June 26, 2020, https://cabar.asia/ru/ drugogo-vyhoda-u-nas-net-u-gossluzhashhih-tadzhikistana-zabirayut-chast-zarplaty
} 
In Tajikistan, as in many authoritarian countries, there is a problem with freedom of speech, "information equality", wide and easy access to the Internet. The process of informatization of public services in the country has just begun and is not widespread as in some countries of Central Asia.

It is worth noting that in Tajikistan (excluding Turkmenistan), the presence of coronavirus was recognized later than everyone else. Many signs indicated the presence of coronavirus in the country, but this was officially recognized only on April 30, before the arrival of the WHO delegation to the country. Further, due to public mistrust of official statistics, the kvtj. info website (Coronavirus Tajikistan) was launched in May 2020, where the population could report deaths from COVID-19 and keep parallel statistics. ${ }^{30}$ However, later this resource was blocked by the Tajik authorities under the pretext of "unreliability" of the data.

A serious problem with the spread of coronavirus and quarantine conditions is access to inexpensive Internet for the education system, where the likelihood of introducing distance education on the ground is very difficult. The monopolization of information services, both technological and in terms of content, makes it difficult for society to gain wide access to information. As experts write, "the emerging discontent in different parts of the republic and social networks created a precedent for protest and destroyed the informal "taboo" on demonstrating disagreement." 31 Thus, the Internet space, in fact, is becoming the only platform where Tajikistanis can express their position and criticize government policies, including the fight against coronavirus.

The Tajik authorities have seriously set their sights on replenishing the state budget at the expense of global Internet platforms: in early November 2020, the parliament adopted amendments to the Tax Code (TC), according to which various global online giants such as Google, Apple, Microsoft, Facebook, and others, those who provide paid services on the territory of the country must pay value added tax (VAT) to the Tajik budget. The introduced amendments, in the opinion of their initiators, will contribute to the further improvement of the tax legislation of Tajikistan and will increase revenues to the state budget. However, online experts interviewed by the analytical platform CABAR.asia say these measures could disrupt the domestic market for online services. ${ }^{32}$

In early 2021, Tajikistan was also the first among Central Asian countries to announce victory over the coronavirus. According to Emomali Rahmon, there are currently no COVID-19 cases in the country, and the pathogen itself has been "completely destroyed." ${ }^{3}$

\footnotetext{
30 "In Tajikistan, a Website for Collecting Information on the Victims of COVID-19 Was Blocked," May 11 2020, https://asiaplustj.info/ru/news/tajikistan/society/20200511/v-tadzhikistanezablokirovali-sait-po-sboru-informatsii-o-pogibshih-covid-19 [In Russian]

${ }^{31}$ Khursand Khurramov, "Protest Moods in Tajik Society in 2020: Breaking the "Taboo" on Demonstrating Dissent?" Radio Ozodi, https://rus.ozodi.org/a/31022250.html [In Russian]

32 "Tajik Government Is to Impose Taxes on Foreign Online Services," CABAR.asia, https://cabar. asia/ru/pravitelstvo-tadzhikistana-hochet-vzimat-nalogi-s-inostrannyh-onlajn-servisov

33 "Tajikistan Has Announced a Complete Victory Over COVID-19," Lenta.ru, January 26, 2021, https://lenta.ru/news/2021/01/26/rakhmon_tad/ [In Russian]
} 
As one can see, in authoritarian states, information policy turns into a megaphone for the political elite pursuing their own "image" interests and not caring about public trust.

Information freedom and the transition to a new technological level of social communications both vertically and horizontally are important from the point of view of broad public participation in the decision-making process, control of budgetary spending on social support of the population.

\section{RECOMMENDATIONS FOR THE MODERNIZATION OF THE PUBLIC MANAGEMENT SYSTEM}

For Tajikistan, in addition to the need to modernize the national health care system, the allocation of funds for the construction of medical hospitals, equipping with the necessary medicines and modern medical equipment, which is very important in the context of the spread of coronavirus, the structural restructuring of public management that meets urgent social needs is especially critical.

The paternalistic system of the political regime in the country requires building a certain model of dialogue with society. Such a model at a given level of development of digitalization in the country seems to be very difficult. In the context of a sufficiently large external dependence of the economy, it is advisable for Tajikistan to pursue a sufficiently flexible and adaptable foreign policy, in particular, experts recommend:

First, the Tajik government needs to try to negotiate with Russia on the introduction of exemptions on patents for migrant workers during the self-isolation regime. This step will be beneficial for both Tajikistan and Russia because migrants bring significant income to both states. In the regime of self-isolation in Russia, migrants have found themselves in a very difficult situation and need the active support of their state.

Secondly, diversification of the food security sphere. Despite certain stocks of essential products, the EAEU member states have limited the export of goods. The most preferential treatment for the import and export of agricultural products is necessary.

Thirdly, in the context of the introduction of quarantine in Tajikistan, it is necessary to develop targeted measures, including special tax "holidays" for small and medium-sized businesses. Proactive incentive support measures, for example, in the field of tourism is needed.

Fourth, a system of measures to support socially vulnerable groups of citizens is also important, for example, in paying for utilities, granting deferrals for loans and payments, developing compensatory mechanisms in the face of forced unemployment. 
Fifth, purposeful modernization of the sphere of providing information services to the population, increasing the speed of the Internet with wide access for the population. The current situation requires adaptation, and the Internet is the most important factor for telecommuting, studying, or doing business. The world has switched to online mode, and in this case, Tajikistan is in a mode of permanent technological lag.

Sixth, it is necessary to modernize the state system for the provision of social services, including medical services, improve social infrastructure, train medical professionals, and create the necessary conditions for them. It is important to quickly study the statistics of the spread of the virus in different countries and the level of exponential growth of infected in the region and the world.

Seventh, it is advisable to create effective and transparent mechanisms of public control over the distribution of aid received from abroad in the context of the coronavirus crisis. 


\section{UZBEK WAY TO FIGHT CORONAVIRUS CRISIS}

\section{DILEMMAS AND SPECIFICS OF PUBLIC MANAGEMENT}

Uzbekistan, as one of the most dynamically developing states in the Central Asian region, faced a choice of dilemmas:

1. implementation of strict quarantine measures to prevent the spread of coronavirus among the population.

2. the adoption of effective measures to stimulate economic growth and "targeted" support for vulnerable groups of the population.

The highest rates of economic growth in the region directed the country's leadership to the second development scenario with a regime of social distancing, self-isolation, and adherence to the hygiene regime of the population, the transition to remote forms of work in a number of sectors of the economy and the socio-cultural sphere.

In Uzbekistan, as well as in Kazakhstan, an Anti-Crisis Fund was formed to mitigate the economic consequences of the spread of coronavirus and slow down economic activity in the amount of 950 million EUR (10 trillion UZS or 1.5\% of GDP). ${ }^{34}$ Specific "targeted" economic measures have been developed to support entrepreneurial activity in a number of strategically important sectors. The National Bank took measures to facilitate refinancing operations for commercial banks and ease restrictions on banks' liquidity requirements. Conditions for increasing liquidity have been created for enterprises and credit lines have been simplified.

\section{Fiscal measures for legal entities:}

- Financing: interest-free loans to businesses in the most affected industries. Granting entrepreneurs with a deferral to repay loans. The classification of loans by quality category has not been changed.

- Taxation: deferred tax payments for businesses for a period of 6 months. Reducing the personal income tax rate for entrepreneurs. Moratorium on tax audits. VAT refund to all textile and cotton companies in order to ensure working capital.

- Anti-Crisis Fund in the amount of 1 billion USD, including the allocation of budgetary funds to the State Fund for the support of entrepreneurship. Reorganization of government organizations.

\footnotetext{
34 "An Anti-Crisis Fund in the Amount of 10 Trillion Sums is About to be Created," Gazeta.uz, March 19, 2020, https://www.gazeta.uz/ru/2020/03/19/anti-crisis-fund/
} 
According to the President of Uzbekistan Shavkat Mirziyoyev, as of May 5, 2 trillion 250 billion UZS (23,887,163 USD) allocated by the anti-crisis fund were spent. ${ }^{35}$ Also, international financial institutions have allocated 500 million USD to fight the pandemic."

In addition, the terms of repayment of existing loans were extended or suspended. As in a number of other Central Asian countries, among other measures, tax incentives and tax holidays for SMEs were provided, the deadlines for submitting tax returns were extended to 3 months, as well as the deadlines for tax payments, tax audits were suspended, or most enterprises were exempted from social contributions. Benefits and preferences affected most of the self-employed and enterprises that provide primary social services to the population. Health support also included the construction of 10 hospitals in Tashkent (10,000 in-patient beds) and in the regions. Medical NGOs were allowed to provide medical services.

The abolition of quarantine was accompanied by a gradual resumption of economic activity in Tashkent from the end of April, and the preparation of a post-quarantine economic plan.

The government of Uzbekistan paid much attention to the issues of rehabilitation of persons in labor migration and their families, in connection with the reduction in the volume of transfers and forced unemployment. Measures were taken to provide public works. In general, we can say that economic activity in the country did not stop, despite the rather serious threat of the spread of the coronavirus. The issues of supporting the economic activity of the population were linked with the tasks of macroeconomic stability and development. This strategy has shown its effect in terms of maintaining optimal economic growth rates and creating favorable conditions for attracting investments and progressive economic recovery, mainly, the stability of the country's production sector. The strategy of openness and the priority of regional cooperation with neighboring countries, implemented by the current leadership of the country, has actualized the issues of maintaining the growth rates of trade turnover of about $30 \%$ per year with the states of the region, which were accumulated in previous years. According to forecasts of international analysts, the volume of external borrowing in 2020-21 in Uzbekistan will grow up to $36 \%$ of GDP.

\section{The volume of external borrowing}

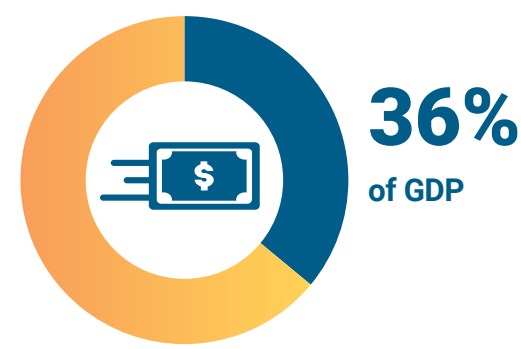

\footnotetext{
35 "Shavkat Mirziyoyev: the Flood Has Become a Bitter Lesson for us," Sputnik News, May 5, 2020, https://uz.sputniknews.ru/20200505/Shavkat-Mirziev-navodnenie-stalo-gorkimurokom-dlya-nas-14060909.html [In Russian]
} 
In Uzbekistan, certain measures were taken for social protection, subsidies were provided, as well as food baskets for the most vulnerable segments of the population. According to the international scale of the Global Health Security Index, which is measured on a scale from 0 to 100, no country from Central Asia has exceeded 50 points, that is, has not surpassed even half. ${ }^{36}$ There were problems in the social system of protection of the population in Uzbekistan at the initial stage, when the Ministry of Employment tried to provide single elderly people with nurses, but did not have accurate data on those people who needed such assistance. Government agencies and the public sector did not immediately manage to reorganize, given that everything came quite unexpectedly. Mobile volunteer groups and civilian initiatives turned out to be faster and more mobile, which were then intercepted by government organizations. Experts criticized the non-working "social elevators" for university graduates and the lack of a transparent approach on the part of government agencies in employment. The reluctance of government agencies to enter into dialogue with civil society activists and volunteers was also noted.

The observers also identified bureaucratic problems with the provision of social assistance to people in a pandemic. So, there were problems with the issuance of pensions and permit stickers for cars. Since there were queues in banks to receive a pension, and queues in front of the branches of agencies that issue stickers. Thus, the receipt of the necessary social assistance was accompanied by complex bureaucratic procedures, which indicates the imperfection of state management to support vulnerable segments of the population in the context of the coronavirus.

In general, the emphasis of state policy was placed on supporting the economically active population, which, according to the country's leaders, "can bear the burden" of social security for those in need. The developed system of local self-government in Uzbekistan made it possible to take custody of those in need. The main social problem was the support of groups of the population dependent on remittances of labor migrants and in connection with their forced unemployment in the context of the coronavirus. In the field of support for labor migrants who found themselves in a foreign land without work and social support, as well as university students, the state provided the opportunity to return to their homeland and receive social support from the state.

In particular, remittances from Russia (which account for $8 \%$ of Uzbekistan's GDP) fell by almost 50\%. ${ }^{37}$ At the same time, according to the Ministry of Labor and Employment of the Republic of Uzbekistan,

\footnotetext{
${ }^{36}$ Marina Marchenko. "The Global Health Security Index Revealed Countries' Unpreparedness for Epidemics and Pandemics," PCR News, October 28, 2019, https://pcr.news/novosti/globalnyy-indeks-bezopasnosti-zdorovya-vyyavil-negotovnost-strank-epidemiyam-i-pandemiyam/ [In Russian]

37 "COVID-19 in Central Asia: Implications and Policy Responses, COVID-19 Crisis Response in Central Asia," OECD, June 4, 2020, https://www.oecd.org/eurasia/competitivenessprogramme/central-asia/COVID-19-crisis-response-in-Central-Asia-Russian.pdf
} 
the official number of registered unemployed is about 2 million people. Support for this category of citizens has become a rather serious "burden" on the budget, which has led to its deficit.

\section{IN GENERAL, THE SPECIFICITY OF THE "UZBEK} CASE" WAS THE "PINPOINT ELABORATION" OF SOCIAL POLICY AND AN ORIENTATION TOWARDS MAINTAINING THE ECONOMIC ACTIVITY OF THE POPULATION AND PRESERVING JOBS.

With regard to human rights, the authoritarian style of government was aimed more at economic expediency than at support of social programs, although the necessary volume of medical services in a pandemic was supported by the state under a fairly strict regime of sanctions against non-compliance with the social distancing regime and necessary personal hygiene (mask requirement, etc.).

\section{INFORMATION SUPPORT OF STATE POLICY}

In a crisis situation comparable to the spread of the coronavirus, in conditions of autocratic political regimes, the infringement of civil rights, in particular freedom of speech, is a common problem. Uzbekistan is no exception. The state, according to experts' observations, provided "dosed information" about what was happening, the measures taken by the state, the criteria for selecting working enterprises in conditions of limited social activity. Repressions against human rights defenders and journalists have intensified. At the same time, as an excuse for repressive actions, autocratic regimes use the arguments of the fight against fakes that sow panic among the population.

As it is known, one of the problems of effectively combating a pandemic is the fight against infodemic, the spread of rumors and fakes. However, in a number of Central Asian countries, in particular, in Uzbekistan, there were facts of using this real problem as a pretext for reprisals against dissidents. There has also been pressure on some bloggers in Uzbekistan.

However, it should be given tribute to the fact that the situation in general in the sphere of freedoms in Uzbekistan has not changed very significantly during the pandemic. However, this area requires further monitoring, since the legitimacy of the ruling regime of President Shavkat Mirziyoyev in the eyes of society has recently decreased significantly, and criticism in social networks towards him has increased. 
In general, during the pandemic, three of the most alarming trends began to be observed in Uzbekistan:

First, this is the government's departure from legal norms in solving problems associated with the crisis, shifting responsibility for such decisions to a commission that does not have sufficiently clearly defined responsibilities and powers.

Second, the government has shown a tendency to relieve itself of responsibility for meeting the basic socio-economic needs of the population sent into forced "self-isolation". And this escape from responsibility takes place despite the fact that the obligations to provide the population with basic living conditions are stipulated by the legislation of Uzbekistan, as well as international norms of law, which the government of the country has undertaken to comply with by signing and ratifying the relevant conventions. As a result, in practice, a significant part of the population was left without means of livelihood during the quarantine regime, while experiencing a number of excessive administrative restrictions, for example, a ban on the use of personal transport, which further aggravates the socio-economic situation. At the same time, the labor rights of citizens who are forcibly sent on unpaid holiday "at their own expense" are violated on a massive scale.

Finally, the government has tended to create two contradictory regimes, restricting the right to movement and work of one part of the economically active population and forcing another part of it to continue working in the midst of the epidemic, thereby placing their health and the health of their family members at an increased risk of contracting coronavirus.

At the same time, these trends were not sufficiently reflected in the information policy of the state. Government agencies did not consider it necessary to inform and explain their policy regarding the coronavirus pandemic, not to mention the need for mass education of the population in the field of public health.

The situation with the provision of donor assistance to the country by the International Financial Institutions, the conditions for the allocation of loans and grants, and decisions made by the state were not properly covered, which created a "shroud of secrecy" and behind-the-scenes decisions regarding the distribution of allocated financial resources. Withholding information is a sign of potential corruption decisions on the part of officials, which significantly reduces public confidence and the authority of the state.

Another problem of the modern development of Uzbekistan is the underdeveloped infrastructure of information support. The transition of the education system to the distance mode was complicated by insufficient digitalization, the "information inequality" of the population, and the implementation of teaching schoolchildren on television without the possibility of feedback between teachers and students. Disruptions in the Internet connection have become a serious problem in the organization of remote forms of social communication in general. 


\section{DISADVANTAGES AND ADVANTAGES OF THE CHOSEN STRATEGY}

In general, it can be said, that the experience of an economic strategy for minimizing costs in the context of a pandemic in Uzbekistan has shown positive results, although many human rights defenders and civil activists criticized the state's insignificant attention to the needs of vulnerable groups of the population, and poor awareness of state policies to counter the spread of coronavirus. "Targeted support" from the state for the economically active population, who were forced to find themselves unemployed (labor migrants), the mechanisms of their labor adaptation in the conditions of the coronavirus crisis with minimal financial costs for the state are of certain interest for the countries of the region that are experiencing similar problems.

Another important "lesson", from our point of view, is the issue of synchronization and coordination of anti-crisis strategies between states. In particular, the first phase of the pandemic in the region demonstrated the effectiveness of such a coordinated approach between government agencies of the countries of the region. The allocation of the necessary resources for the preparation of medical infrastructure, the coordination of transport, border and other restrictions, sanitary norms and hygiene standards is a positive experience of interaction between the states of the region during a pandemic, which made it possible to avoid disastrous consequences. It seems that in the future, there is a need for a coordinated information and educational policy on alerting the population about emerging threats to the health of the population of the regions (outbreaks of epidemics in certain localities), the necessary preventive measures, algorithms and treatment protocols, the joint development of vaccines and their adaptation. The Uzbek system of public administration, from our point of view, needs more openness, transparency of decisions, closer interaction with civil society, the use of international experience in combating the pandemic

For a country with significant industrial potential among the Central Asian republics, the pandemic situation has shown Uzbekistan's serious dependence on the import of medical equipment and anti-epidemiological medicines as a result of the lack of production of its own medical products, equipment, and a significant nomenclature of medicaments. Obviously, this problem can become the subject of interstate interaction in terms of cooperative ties between the Central Asian states, which have the appropriate groundwork and replenishment resources. 


\section{CONCLUSION}

The COVID-19 coronavirus pandemic has posed a major challenge for all Central Asian countries, albeit to varying degrees. However, there are a number of common features of how countries respond to this crisis. We can say that the pandemic has exposed "generic" negative signs in the states of the region. These include the ineffectiveness of state institutions and the underdevelopment of the legal and civil culture of the population, the corruption of power structures, the dosed and censored by the state information policy. The practically absence of analytical support for the policy of combating the pandemic, forecasting, and designing effective approaches had a significant impact on the pace and scale of its spread. As a result, states were forced to focus more on the international practice of combating coronavirus and substantial humanitarian aid from outside. One of the major costs was the digital divide, which reduced the impact of decisions and recommendations, with the transfer of many institutions to telecommuting and the provision of important services to society.

The shortcomings of public health systems in individual countries also affected the lack of region-wide approaches, the development of which is an urgent need. The coronavirus pandemic actually dragged the countries of the region into a rather protracted political and economic crisis with unpredictable consequences. In Kyrgyzstan, the pandemic and the government's ineffective policy towards combating it became one of the triggers of the change of power in the country. It is obvious that not only individual countries, but also the region as a whole, is today in a state of alarming anticipation of the outcome of the pandemic, tests of the viability of state systems, the stability of economies and the strength of citizens' trust in government structures. Also, the region is in the focus of the competition between the leading international centers of power among themselves on the "platform" of Central Asia against the backdrop of a pandemic. 


\section{REFERENCE LIST}

1. "600 Billion Tenges Will be Allocated to Banks for Lending to SMEs in a Crisis," Zakon. kz, March 20, 2020,

https://www.zakon.kz/5012701-600-mlrd-tenge-vydelyat-bankam-dlya.html [In Russian]

2. "An Anti-Crisis Fund in the Amount of 10 Trillion Sums is About to be Created," Gazeta.uz, March 19, 2020, https://www.gazeta.uz/ru/2020/03/19/anti-crisis-fund/

3. "Anti-crisis Measures of the Government: Resumption of Economic Growth and Support for SMEs," Official information source of the Prime-Minister of Republic of Kazakhstan, https://primeminister.kz/ru/news/reviews/antikrizisnye-mery-pravitelstva-vozobnovlenie-rosta-ekonomiki-i-podderzhka-msb-862620 [In Russian]

4. "Birtanov's Arrest was Extended Until the End of February," Kursiv.kz, January 20, 2021, https://kursiv.kz/news/obschestvo/2021-01/birtanovu-prodlili-arest-do-konca-fevralya [In Russian]

5. "COVID-19 in Central Asia: Implications and Policy Responses, COVID-19 Crisis Response in Central Asia," OECD, June 4, 2020, https://www.oecd.org/eurasia/competitiveness-programme/central-asia/COVID-19-crisis-response-in-Central-Asia-Russian.pdf.

6. "Educational Inequality: In Kyryzstan, Only One Third of Families have a Computer or Tablet," Media Sabak, https://mediasabak.org/ru/news/209/ [In Russian]

7. "Global Economic Prospects Europe and Central Asia Regional Overview," World Bank, January 2021, http://pubdocs.worldbank.org/en/996111599838731966/GlobalEconomic-Prospects-January-2021-Regional-Overview-ECA-RU.pdf

8. "In Recent Months, Migrants' Remittances have Increased - Data from the NBKR," December 19, 2020, https://ru.sputnik.kg/migration/20201219/1050823724/ kyrgyzstan-perevody-migranty.html [In Russian]

9. "In Tajikistan, a Website for Collecting Information on the Victims of COVID-19 Was Blocked," May 11 2020, https://asiaplustj.info/ru/news/tajikistan/society/20200511/v-tadzhikistane-zablokirovali-sait-po-sboru-informatsii-o-pogibshih-covid-19 [In Russian]

10. "Minister of Culture and Tourism of Kyrgyzstan: It Will Take Several Years to Restore Tourism in the Country After the Pandemic", Interfax, https://www.interfax.ru/interview/722563 [In Russian]

11. "On the Approval of the Employment Roadmap for 2020 - 2021: Order of the Prime Minister of the Republic of Kazakhstan dated March 27, 2020, No. 55-r" https://adilet.zan.kz/rus/docs/R2000000055 [In Russian]

12. "Shavkat Mirziyoyev: the Flood Has Become a Bitter Lesson for us," Sputnik News, May 5, 2020, https://uz.sputniknews.ru/20200505/Shavkat-Mirziev-navodnenie-stalogorkim-urokom-dlya-nas-14060909.html [In Russian]

13. "Small and Medium Enterprise (SME) Sector Survey," Halyk Finance, October 23, 2020, https://halykfinance.kz/download/files/analytics/sme2020.pdf [In Russian]

14. "Tajik Government Is to Impose Taxes on Foreign Online Services," CABAR.asia, https://cabar.asia/ru/pravitelstvo-tadzhikistana-hochet-vzimat-nalogi-s-inostrannyhonlajn-servisov 
15. "Tajikistan Has Announced a Complete Victory Over COVID-19," Lenta.ru, January 26, 2021, https://lenta.ru/news/2021/01/26/rakhmon_tad/ [In Russian]

16. "Tajikistan Requests the Previous Loans' Deferral and Simultaneously Applies for the New Ones," CABAR.asia, January 26, 2021, https://cabar.asia/ru/ tadzhikistan-prosit-otsrochki-po-starym-kreditam-i-odnovremenno-prosit-novye

17. "The Amount of Remittances in Tajikistan are Decreasing, Income of Citizens is Falling, and Prices are Rising," CABAR.asia, December, 1 2020, https://cabar.asia/ru/v-tadzhikistane-obemy-denezhnyh-perevodov-sokrashhayutsya-dohody-grazhdan-padayut-tsenyrastut [In Russian]

18. "Tokayev: The Fight Against Coronavirus Cost Kazakhstan Almost 6 Trillion Tenge," Informburo, May 5, 2020, https://informburo.kz/novosti/tokaev-borba-s-koronavirusom-oboshlas-kazahstanu-pochti-v-6-trln-tenge--106068.html [in Russian]

19. "We Have no Other Choice." Salary is Partially Taken Away from Civil Servants in Tajikistan," CABAR.asia, June 26, 2020, https://cabar.asia/ru/ drugogo-vyhoda-u-nas-net-u-gossluzhashhih-tadzhikistana-zabirayut-chast-zarplaty

20. Arsen Usenov, "Problems of Ensuring the National Security of Kyrgyzstan amidst the Current Crisis," CABAR.asia, April 20, 2020, https://cabar.asia/ru/problemy-obespecheniya-natsionalnoj-bezopasnosti-kyrgyzstana-v-usloviyah-nastupivshego-krizisa [In Russian]

21. Ayim Saurambayeva, "Difficulties of Transition to Distance Education: the Case of Kazakhstan," CABAR.asia, August 24, 2020, https://cabar.asia/ru/trudnosti-perehoda-na-distantsionnoe-obrazovanie-kejs-kazahstana [In Russian]

22. Ilham Saypidinov, "The Growth of Gold and Foreign Exchange Reserves of the National Bank of the Kyrgyz Republic against the Background of a Decline in GDP is One of the Reasons for the Devaluation of the Som," Akchabar,

https://www.akchabar.kg/ru/article/opinion/rost-zolotovalyutnyh-rezervov-nacionalnogo-banka-na-fone-spa/ [In Russian]

23. Imanbekova Nazik and Khasanova Savia, "Economy and COVID-19 in Central Asia," Central Asian Analytical Network, August, 12, 2020, https://caa-network.org/archives/19734 [In Russian]

24. Lyudmila Khasanova, "Bureaucratic Alibi and Psychological Traps: How Kyrgyzstan Allowed the Outbreak of Coronavirus," Central Asian Analytical Network, https://caa-network.org/archives/20124 [In Russian]

25. Marina Marchenko. "The Global Health Security Index Revealed Countries' Unpreparedness for Epidemics and Pandemics," PCR News, October 28, 2019, https://pcr.news/novosti/globalnyy-indeks-bezopasnosti-zdorovya-vyyavil-negotovnost-stran-k-epidemiyam-i-pandemiyam/ [In Russian]

26. Rabiga Dysengulova, "There is One Suspect in the SK-Pharmacia Case," Tengri News, January 29, 2021, https://tengrinews.kz/crime/v-dele-sk-farmatsii-odin-podozrevaemyiy -427405/ [In Russian]

27. Yrysbek Ulukbek ulu, "Remittances from Russia have Plummeted: Kyrgyzstan will Suffer More than it Seemed," Radio Azattyk, https://rus.azattyk.org/a/30611906.html [In Russian] 
28. Zamira Kozhobaeva, "COVID-19 in the Kyrgyz Republic: Real mortality may be three times higher than official data," Radio Azattyk, January 20, 2021,

https://rus.azattyk.org/a/covid-19-v-kr-realnaya-smertnost-vyshe-ofitsialnyh-dannyh-vtri-raza/31053269.html [In Russian]

29. Zhamilya Zhakypbekova, "Public debt, Poverty and Migration. Will the new Constitution Help Solve these Problems?" Economist, https://economist.kg/2020/11/24/ gosdolg-bednost-i-migraciya-pomozhet-li-novaya-konstituciya-reshit-eti-problemy/

30. Bakyt Asanov, "The former-head of the Ministry of Health of the Kyrgyz Republic, Suspected of Corruption, Was Hospitalized After Interrogation," Radio Azattyk, July 11, 2020, https://rus.azattyk.org/a/30720815.html [In Russian]

31. Khursand Khurramov, "Protest Moods in Tajik Society in 2020: Breaking the "Taboo" on Demonstrating Dissent?" Radio Ozodi, https://rus.ozodi.org/a/31022250.html [In Russian]

32. Sergey Smirnov, "The Retreat from Kazakhstan Continues," Rhythm of Eurasia, December 17, 2020, http://www.ritmeurasia.org/news--2020-12-17--ishod-iz-kazahstana-prodolzhaetsja-52415?fbclid=IwAR1S-Du_UYIFX-d076cNhkHtoPGapKy1h_ nga7wEFcutbBBM0ZKBbxyxS30 [In Russian] 


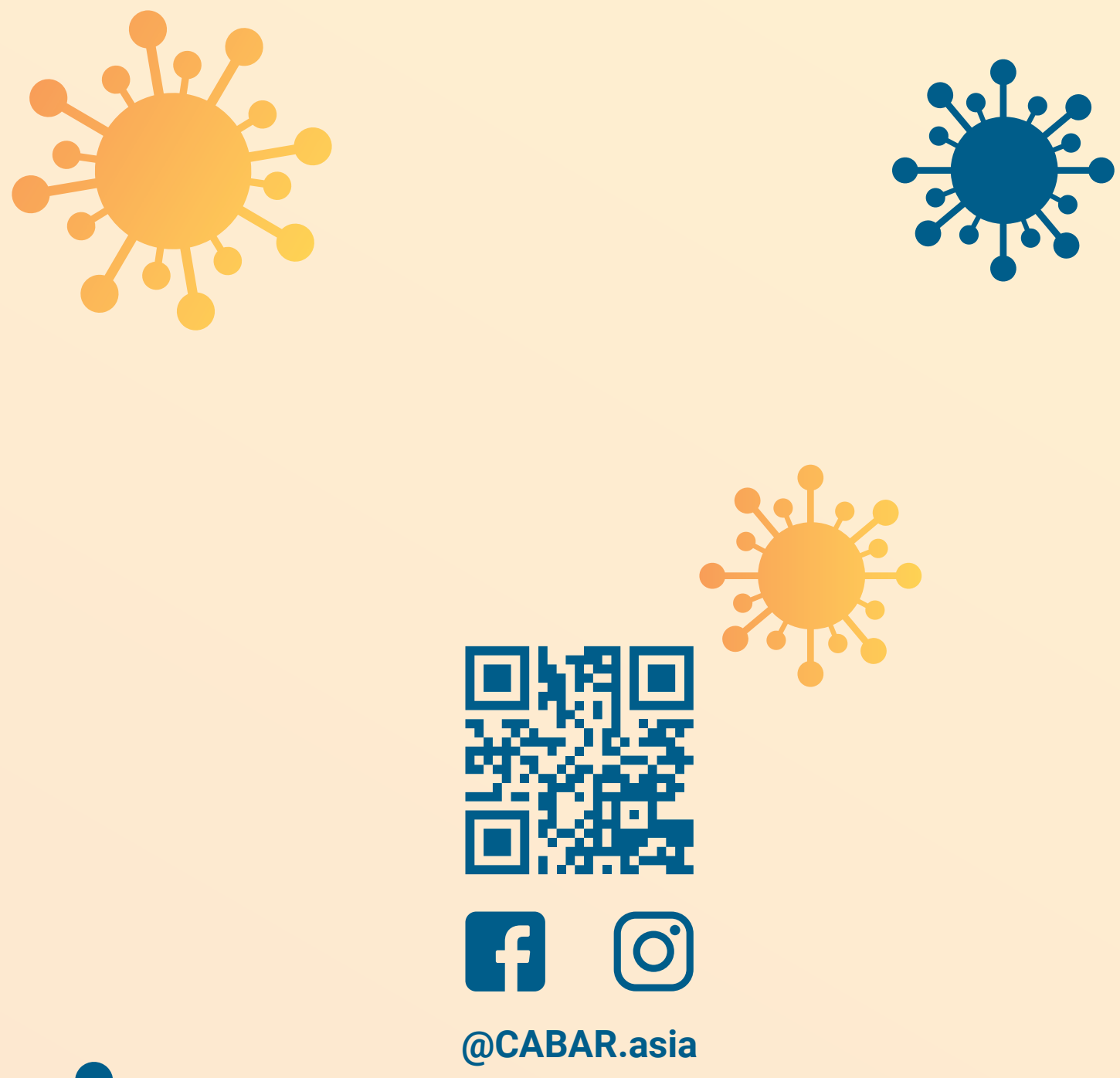

@CABAR.asia
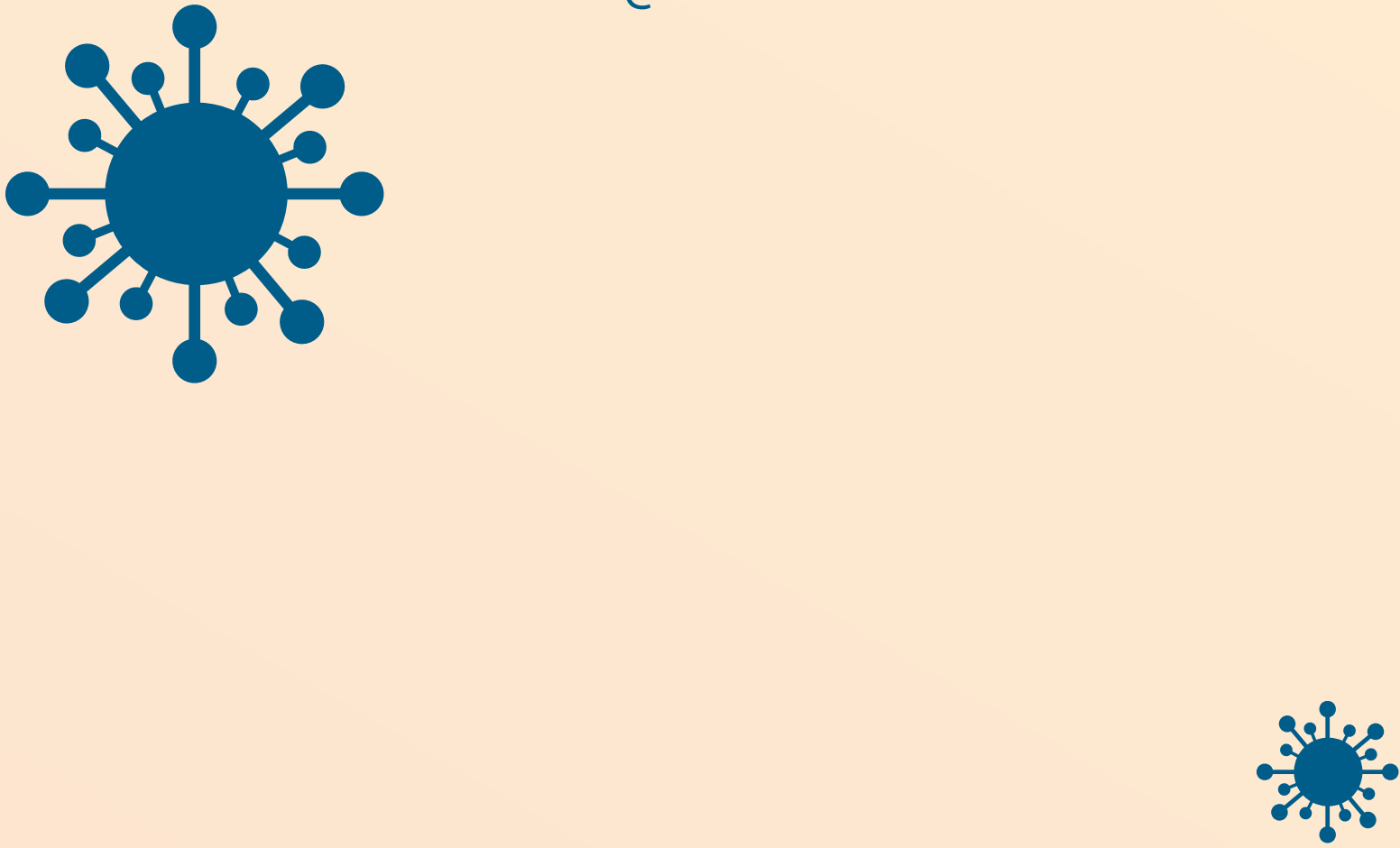